\title{
A note on strandings of Bryde's whales (Balaenoptera edeni) in the southwestern Atlantic
}

\author{
Eduardo Cabral Casado Lima ${ }^{1}$ \\ Contacte-mail: eduardocclima@hotmail.com
}

\begin{abstract}
This study analysed 74 records of Bryde's whale strandings in jurisdictional Brazilian waters in order to further understanding of strandings in the region. Collation of records published in the media (newspapers, magazines, TV, online sources) and in peer-reviewed articles revealed 74 documented strandings between 1972 and 2015 along the coasts of Rio Grande do Sul, and Rio de Janeiro, Bahia and Maranhão states. Statistically significant differences were found between the frequencies of strandings in relation to Brazilian regions $\left(\chi^{2}=103.17\right)$, with the highest abundance found in the Southeast region (71.62\%). Statistically significant differences were also observed between stranding frequency and sexual maturity $\left(\chi^{2}=12.31\right)$, with a higher abundance for sexually mature females $(54.25 \%)$. No statistically significant difference between the stranding frequency in relation to seasonality $\left(\chi^{2}=2.8\right)$ was observed. No statistically significant difference between stranding frequency for males and females was found $\left(\chi^{2}=3.12\right)$. A simple linear regression showed an increasing trend of Bryde's whale strandings from the $1980 \mathrm{~s}$ onwards, possibly due to population growth, increased monitoring throughout the Brazilian coast, and/or an increase in anthropogenic threats.
\end{abstract}

KEYWORDS: BRAZIL; BRYDE'S WHALE; STRANDINGS

\section{INTRODUCTION}

The Bryde's whale (Balaenoptera edeni) is a predominantly tropical species, sighted in Brazil in both coastal and oceanic areas (Andriolo et al., 2010; Figueiredo et al., 2014; Lodi et al., 2015; Siciliano et al., 2004), especially in the southeast of the country (de Moura and Siciliano, 2012; Lodi and Borobia, 2013). This study collates records on Bryde's whale strandings in order to obtain a general understanding of the species in Brazil, and specifically to: (a) verify if a certain region in the country displays a higher stranding frequency; (b) assess the seasonality of the strandings; (c) compare the sexual frequency of stranded specimens; (d) characterise the sexual maturity of stranded animals; and (e) determine possible trends in the stranding incidences in recent decades.

The occurrence and reporting of cetacean stranding events can be influenced by a number of factors, and reported trends are often questioned. The effects of monitoring coverage and environmental variations, such as tides, winds and ocean currents (which can carry carcasses to different beach locations), lead to debates on whether stranding records do in fact represent the abundance of a certain population (Meager and Limpus, 2014; Meager and Sumpton, 2016; Peltier et al., 2014). However, strandings data can be used as an additional tool to evaluate possible patterns related to the general distribution of a species, as records may reflect the occurrence frequency in a given area (Maldini et al., 2005). Strandings data can also verify whether the gathering of records has increased in recent times and thus inform future conservation efforts (Lima et al., 2006).

\begin{abstract}
METHODS
A literature search using Google Scholar ${ }^{2}, \mathrm{SciELO}^{3}$ and The Web of Science ${ }^{4}$ databases was conducted during the months of July-November 2015 using the following search terms: 'baleen-de-bryde', 'Balaenoptera edeni', 'Balaenoptera brydei', 'strandings', and 'Brazil'. Results were then manually sorted and only articles relevant to the study were selected. This research was complemented with items from online communication channels such as local newspaper reports (O Globo, Zero Hora, Correio do Povo), and Google ${ }^{5}$ searches using the terms 'baleia-de-bryde', 'strandings' and 'Brazil'. Only records containing photographs or videos of diagnostic features (i.e. rostral ridges) were used to confirm positive identification of the species. In total, 74 records documenting strandings of Bryde's whales between 1972 and 2015 were obtained (see Table 1).
\end{abstract}

\section{Strandings by region}

Records were grouped regionally from South to North by date and according to the Brazilian regional classification (South, Southeast and Northeast). Records were then plotted on a map with the aid of a geographic projection using DATUM SIRGAS 2000, available with the software package ArcMap (ArcGis Desktop 10.5 Esri) (Fig. 1). Where geographic coordinates of strandings were not available, coordinates were estimated from the central point of the cited location. These coordinates were based on the geographical

\footnotetext{
${ }^{2}$ https://scholar.google.com [Accessed 22 August 2015].

${ }^{3}$ https://www.scielo.org/ [Accessed 15 September 2015].

${ }^{4}$ http://wokinfo.com/ [Accessed 2 October 2015].

${ }^{5}$ https://www.google.com.br [Accessed 20 October 2015].
}

${ }^{1}$ Laboratório de Bioacústica e Ecologia de Cetáceos, Departamento de Ciências Ambientais, Instituto de Florestas, Universidade Federal Rural do Rio de Janeiro, BR 465, km 7, Seropédica, RJ, 23890-000, Brazil, and Programa de Pós-Graduação em Biologia Animal, Universidade Federal Rural do Rio de Janeiro, Rodovia BR 465, km 7, Seropédica, Rio de Janeiro 23890-970, Brazil. 
Table 1

Strandings records of Bryde's whales in the south, southeast and northeast of Brazil between 1972 and $2015(n=74)$.

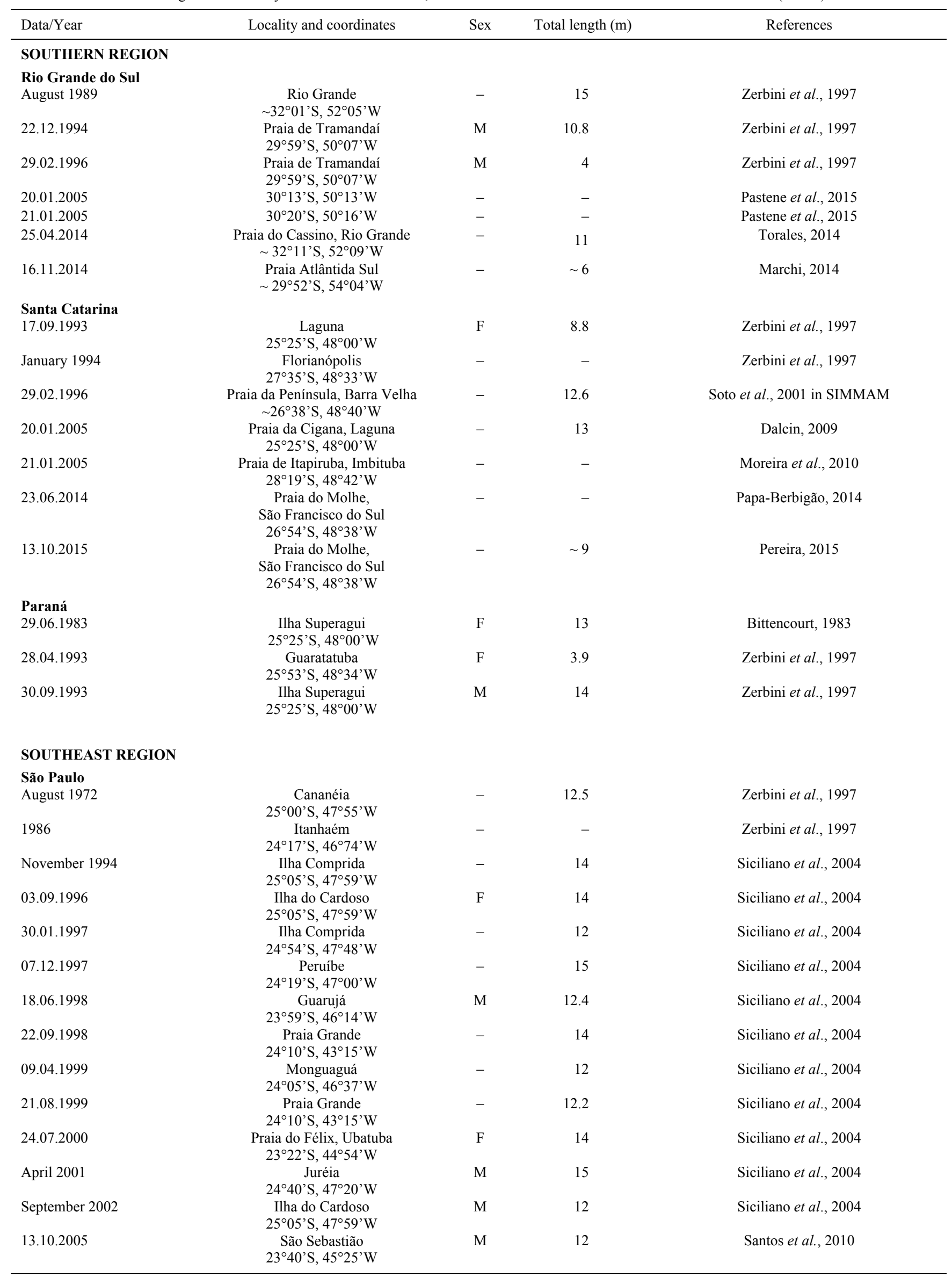


Table 1 (continued).

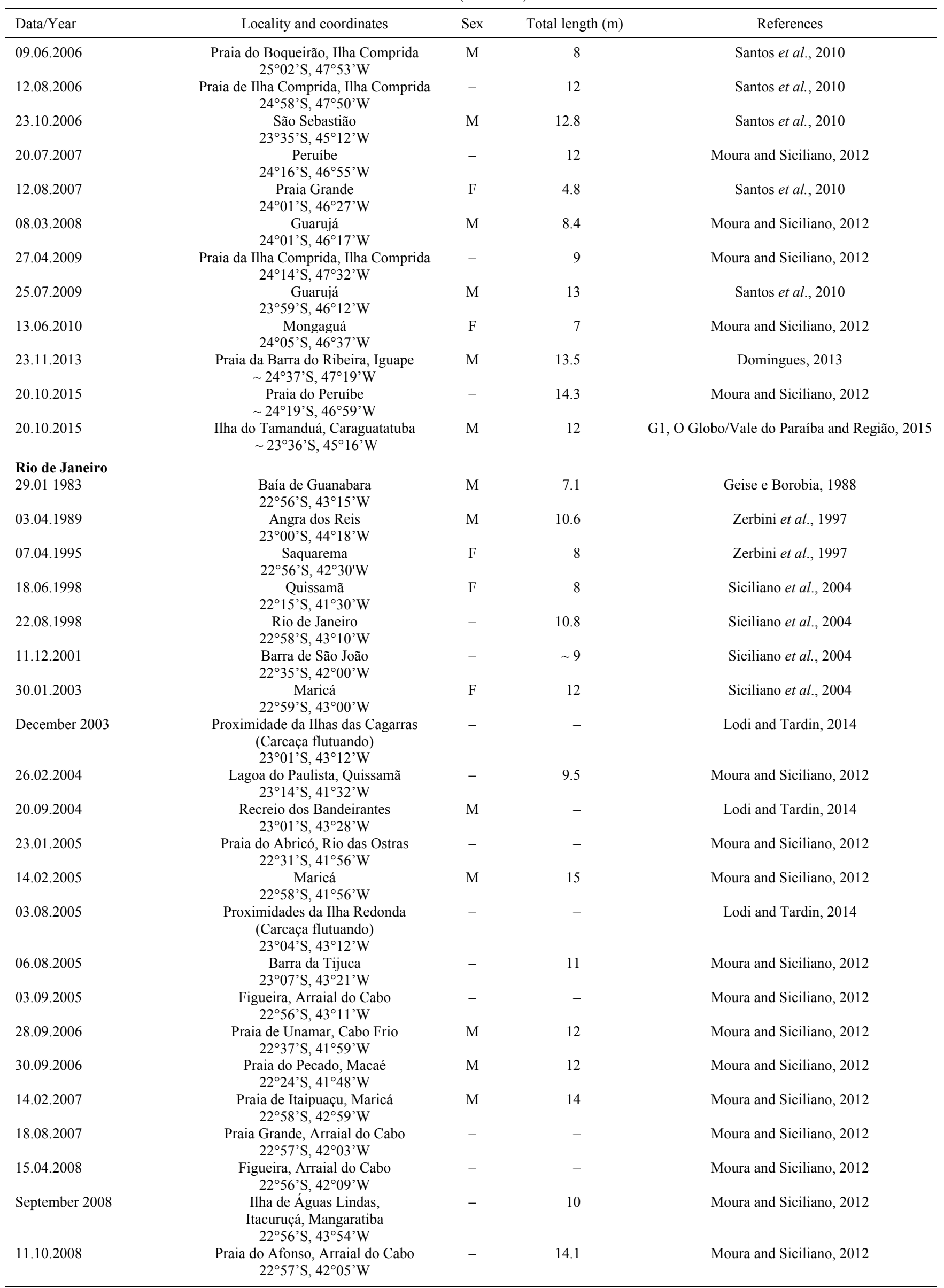


Table 1 (continued)

\begin{tabular}{|c|c|c|c|c|}
\hline Data/Year & Locality and coordinates & Sex & Total length (m) & References \\
\hline 14.10 .2008 & $\begin{array}{l}\text { Praia das Palmeiras, Caraguatatuba } \\
23^{\circ} 40^{\prime} \mathrm{S}, 45^{\circ} 25^{\prime} \mathrm{W}\end{array}$ & - & 7 & Moura and Siciliano, 2012 \\
\hline 08.03 .2010 & $\begin{array}{l}\text { Lagoa Comprida, Jurubatiba, Macaé } \\
23^{\circ} 16^{\prime} \mathrm{S}, 41^{\circ} 39^{\prime} \mathrm{W}\end{array}$ & M & 7.17 & Moura and Siciliano, 2012 \\
\hline 30.10 .2010 & $\begin{array}{l}\text { Praia de Carapebus } \\
22^{\circ} 15^{\prime} \mathrm{S}, 41^{\circ} 36^{\prime} \mathrm{W}\end{array}$ & $\mathrm{F}$ & 8.8 & Moura and Siciliano, 2012 \\
\hline 09.03 .2011 & $\begin{array}{l}\text { Praia do Visgueiro, Quissamã } \\
22^{\circ} 13^{\prime} \mathrm{S}, 41^{\circ} 31^{\prime} \mathrm{W}\end{array}$ & - & 8 & Moura and Siciliano, 2012 \\
\hline 20.03 .2012 & $\begin{array}{l}\text { Proximidades do Vidigal } \\
\text { (Carcaça flutuando) } \\
22^{\circ} 59^{\prime} \mathrm{S}, 43^{\circ} 14^{\prime} \mathrm{W}\end{array}$ & - & - & Lodi and Tardin, 2014 \\
\hline \multicolumn{5}{|c|}{ NORTHEAST REGION } \\
\hline \multicolumn{5}{|l|}{ Bahia } \\
\hline 30.09 .1981 & $\begin{array}{c}15 \mathrm{~km} \text { do Rio Paraguaçu, Maragogipe, } \\
\text { Baía de Todos os Santos } \\
12^{\circ} 48^{\prime} \mathrm{S}, 38^{\circ} 55^{\prime} \mathrm{W}\end{array}$ & $\mathrm{F}$ & 14 & Lima et al., 2006 \\
\hline \multicolumn{5}{|l|}{ Maranhão } \\
\hline 1991 & $\begin{array}{l}\text { Praia do Ciumal, } \\
\text { Delta do Parnaíba } \\
\sim 2^{\circ} 41^{\prime} \mathrm{S}, 42^{\circ} 08^{\prime} \mathrm{W}\end{array}$ & - & 10 & Zerbini et al., 1997 \\
\hline 1996 & $\begin{array}{l}\text { Ilhas Canárias, Delta do Parnaíba } \\
\qquad 2^{\circ} 41^{\prime} \mathrm{S}, 42^{\circ} 08^{\prime} \mathrm{W}\end{array}$ & - & & Zerbini et al., 1997 \\
\hline 1999 & $\begin{array}{l}\text { Ilha do Caju, Delta do Parnaíba } \\
\sim 2^{\circ} 41^{\prime} \mathrm{S}, 42^{\circ} 09^{\prime} \mathrm{W}\end{array}$ & - & - & Magalhães et al., 2008 \\
\hline
\end{tabular}

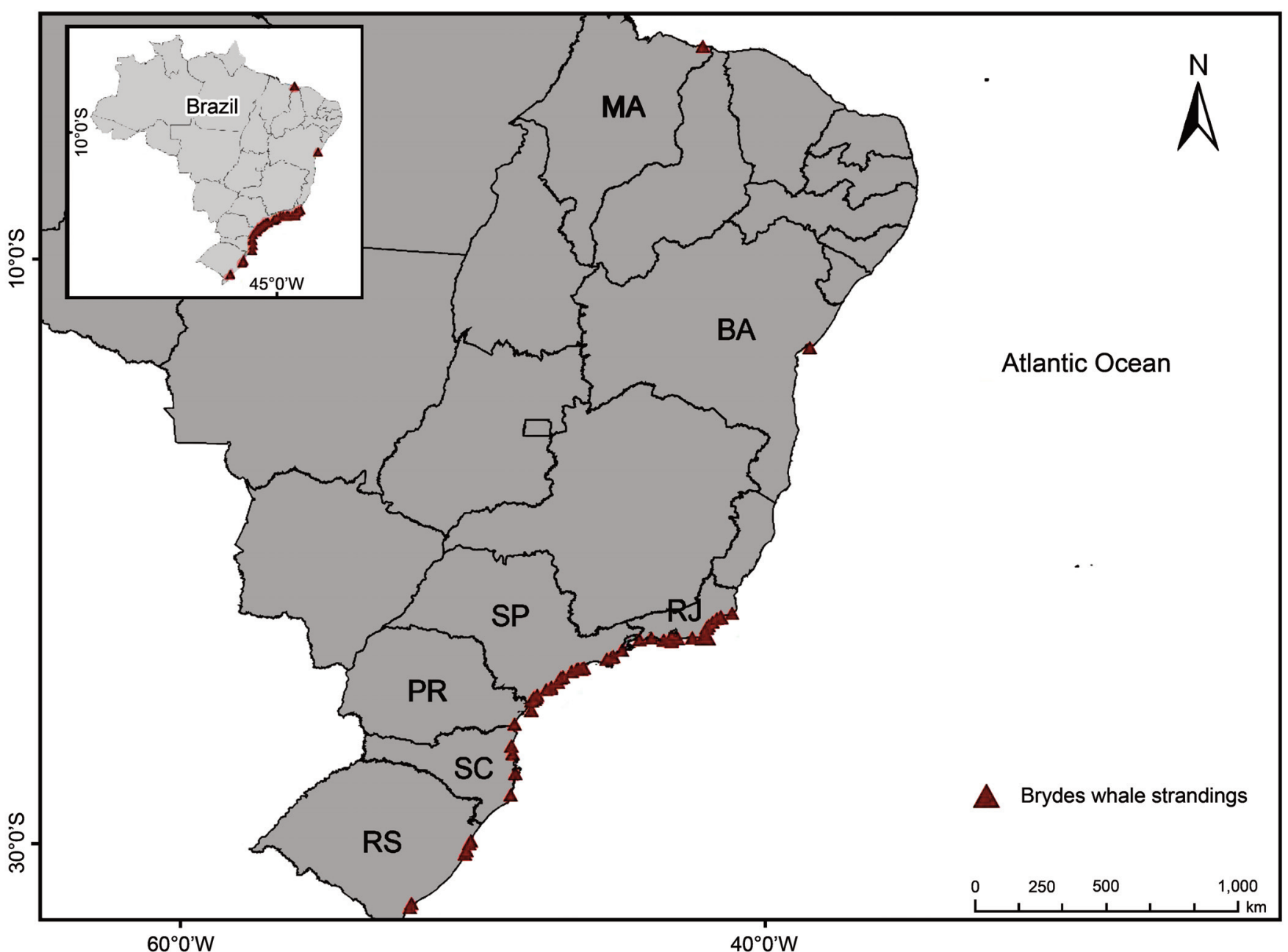

Fig. 1 Bryde's whale strandings in Brazil between 1972 and 2015: Maranhão (MA); Bahia (BA); Rio de Janeiro (RJ); São Paulo (SP); Paraná (PR); Santa Catarina (SC); and Rio Grande do Sul (RS). 
coordinates provided by WGE98 (Google Earth software) and were also plotted using ArcMap (ArcGis Desktop 10.5 Esri) to standardise the coordinates of all compiled records.

\section{Seasonality}

To assess potential seasonality trends data were categorised according to four seasons: January to March (summer); April to June (autumn); July to September (winter); and October to December (spring) (de Moura and Siciliano, 2012).

\section{Sexual maturity}

To categorise the sexual maturity of the stranded specimens, Bryde's whales were classified as juvenile $(\leq 8 \mathrm{~m})$, sexually immature $(>8 \mathrm{~m}$ and $\leq 11.2 \mathrm{~m})$ and sexually mature $(>11.2 \mathrm{~m})$ using two cetacean identification guides (Jefferson et al., 2008; Kato and Perrin, 2009).

\section{$\operatorname{Sex}$}

Gender was determined when the whale position allowed for an overview of the ventral region or when the carcasses were dissected, according to documented records published in the articles of de Moura and Siciliano (2012), Santos et al. (2010) and Siciliano et al. (2004) or from local newspaper reports. When the sex of the specimens was not documented from morphological evidence due to the advanced decomposition of the carcass, gender was considered undetermined. The Chi-square test was not applied when sex was undetermined.

\section{Statistical analyses}

A Chi-square test was used to attest significant differences between observed and expected frequencies, with a significance level set at $\alpha=0.05$. The test was applied to verify potential differences between strandings' frequency in Brazilian regions, seasonality, sex and sexual maturity of the specimens. A simple linear regression was used to determine trends in stranding incidences between 1970 and 2010, using the STATISTICA software package.

\section{RESULTS AND DISCUSSION}

\section{Strandings by region}

A total of 74 Bryde's whale strandings were documented in Brazil between 1972 and 2015 in the states of Rio Grande do Sul and Rio de Janeiro, Bahia and Maranhão. The highest frequency of strandings $(71.6 \%, \mathrm{n}=53)$, was observed in the Brazilian southeast region. The most representative states in this region were Rio de Janeiro with 36.5\% $(\mathrm{n}=27)$, and São Paulo with $35.1 \%(n=26)$ The south region recorded $(23 \%$ $\mathrm{n}=17)$ with the states of Rio Grande do Sul $(9.4 \% \mathrm{n}=7)$, Santa Catarina $(9.4 \% \mathrm{n}=7)$ and Paraná $(4 \% \mathrm{n}=3)$. The Northeast region presented a frequency of $(5,4 \% \mathrm{n}=4)$ with the states of Maranhão $(4 \% \mathrm{n}=3)$ and Bahia $(1.3 \% \mathrm{n}=1)$. A statistically significant difference of strandings frequency was observed among regions southeast, south and northeast $\left(\chi^{2}=103.17 ; \mathrm{SD}=0.3430 \mathrm{p}<0.05\right)(\mathrm{de}$ Moura and Siciliano, 2012; Gonçalves and Andriolo, 2006; Siciliano et al., 2004; Zerbini et al., 1997). Conversely, the number of strandings documented in the northeast and north regions was either low or non-existent. This was probably related to the low monitoring efforts carried out in these regions as this species presents a predominantly tropical distribution. Bryde's whales associate with regions of upwelling and consequently, with areas of high productivity (Gallardo et al., 1983; Kerosky et al., 2012; Pardo and Palacios, 2006; Tershy et al., 1990). Examples of upwelling regions are the Chilean coast (Gallardo et al., 1983), South Africa (Best, 2001), the tropical East of the Pacific Ocean (Palacios, 2003), the Santa Marta region of the Caribbean and the recess of Southern California (Kerosky et al., 2012), while productive regions include the Ballenas Channel in the Gulf of California (Tershy et al., 1990), in the continental shelf division and in the northeastern Gulf of Mexico (Davis et al., 1998).

\section{Sightings}

Sighting records for this species are also higher in the Brazilian Southeast region (Gonçalves and Andriolo, 2006; Lodi and Borobia, 2013; Siciliano et al., 2004; Zerbini et al., 1997), especially within the state of Rio de Janeiro. This may be related to the abundance and availability of food resources in the productive waters of the region, such as sardines (Sardinella brasiliensis), one of the main dietary items of this species (de Moura and Siciliano, 2012; Figueiredo et al., 2014).

\section{Seasonality}

Seasonality was evaluated for $94.6 \%(n=70)$ of the strandings records. The highest stranding frequency was observed in winter $(32.8 \%)$, followed by summer $(25.7 \%)$. The highest number of records was observed in August $(\mathrm{n}=11)$ and September $(\mathrm{n}=11)$. No statistically significant seasonality was observed for strandings frequency $\left(\chi^{2}=2.8\right.$, $\mathrm{SD}=0.0487, \mathrm{p}>0.5)$. The results observed here corroborate other studies which also report an absence of seasonal stranding patterns, despite higher records in winter (de Moura and Siciliano, 2012; Siciliano et al., 2004). The higher frequency of winter strandings could be explained by the combination of south and southwest winds, particularly common in winter, and intense ocean currents bringing carcasses to Brazilian coasts (de Moura and Siciliano, 2012).

Sex

Sex was determined for $43.2 \%(n=32)$ of the strandings records. Frequencies of $65.6 \%(n=21)$ males and $34.4 \%$ $(\mathrm{n}=11)$ females were observed. Although higher frequencies of males were observed, this was not statistically significant $\left(\chi^{2}=3.12, \mathrm{SD}=0.2209, \mathrm{p}>0.10\right)$. This can be explained by the high number of records where sex was not identified, probably due to the decomposition state of the carcasses. The findings of this study support those of Siciliano et al. (2004), de Moura and Siciliano (2012) and (Santos et al., 2010), which also indicate a higher frequency of male strandings in Brazil.

\section{Sexual maturity}

Data on the sexual maturity of stranded specimens were available in $79.7 \%(n=59)$ of the evaluated strandings records. The total length of the individuals ranged from $3.8 \mathrm{~m}$ to $15 \mathrm{~m}$. Juveniles presented a frequency of $20.3 \%(n=12)$, followed by sexually immature $(25.4 \%, \mathrm{n}=15)$ and mature 


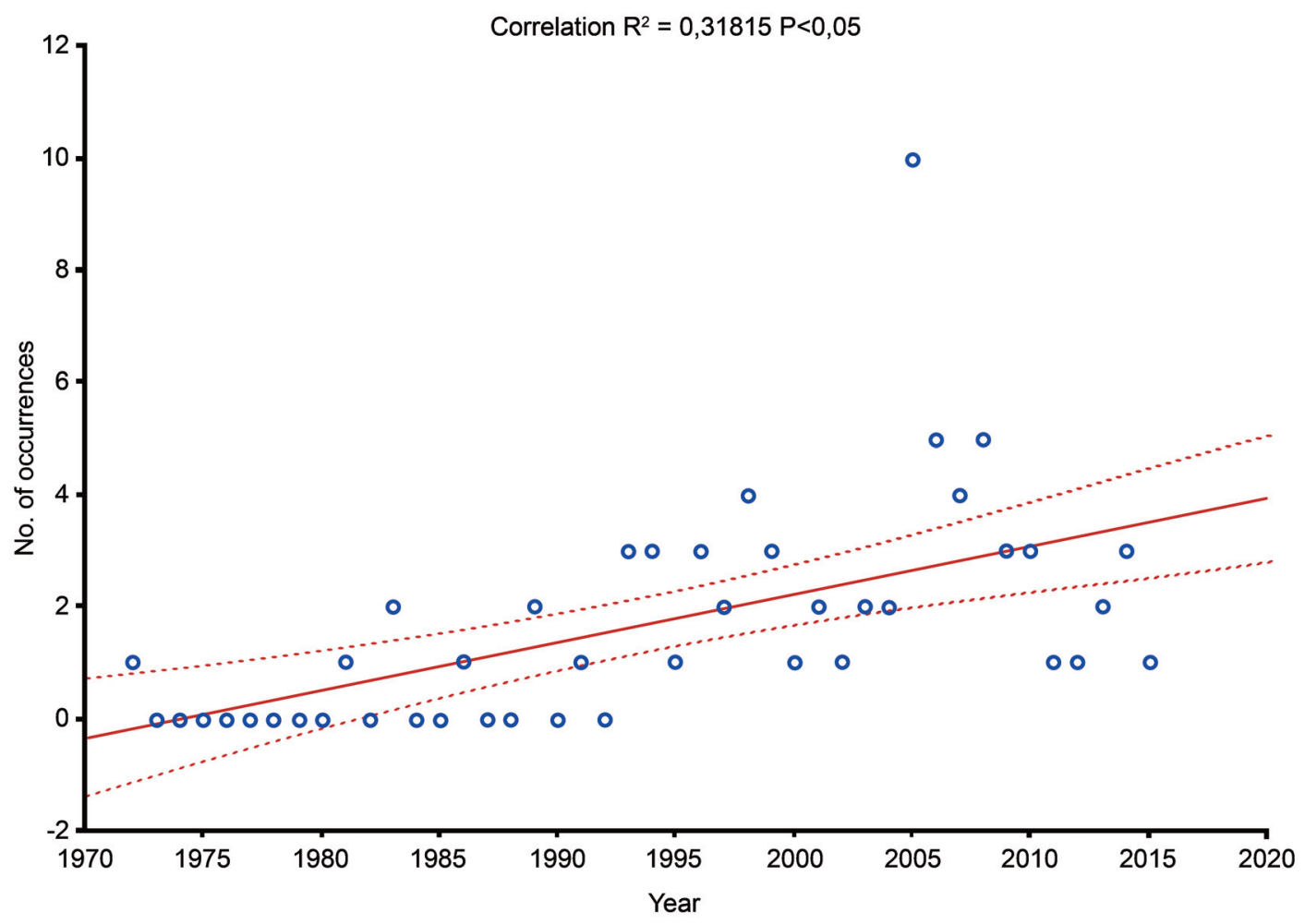

Fig. 2 Simple linear regression of the number Bryde's whales stranded in Brazil between 1972 and 2015.

$(54.3 \%, \mathrm{n}=32)$ individuals. A statistically significant different strandings frequency was found among sexual maturity categories $\left(\chi^{2}=12.31, \mathrm{SD}=0.1829, \mathrm{p}<0.05\right)$. The highest prevalence of juveniles $(n=12, \leq 8 \mathrm{~m})$ was observed in the summer and autumn, with four records in March and four in June. Juvenile sightings were also recorded in Búzios in the autumn (Figueiredo et al., 2014) and in Cabo Frio in the summer (de Moura and Siciliano, 2012). Regarding sexually mature specimens $(>11.2 \mathrm{~m}), 32$ records were found, with a higher prevalence in the winter and spring, mainly in July (three records) and October (eight records). The preliminary results found here suggest a need for further investigation into the still unknown reproductive aspects of Bryde's whales in Brazil.

\section{Incidences of strandings}

Although the use of a simple linear regression does not allow for extrapolations, a positive relationship was observed between the number of strandings between 1972 and 2015 $\left(\mathrm{R}^{2}=0.31815 ; \mathrm{p}<0.05\right)$ (Fig. 2). A trend towards an increase of Bryde's whale strandings from the 1980s onwards was identified, allowing for the prediction that the increase may continue. This can be related to a number of factors, including: (a) population growth due to the protection of the species after the end of commercial whaling, as has occurred in populations of southern right whales (Eubalaena australis) (Groch et al., 2005) and humpback whales (Megaptera novaengliae) (Zerbini et al., 2010); (b) an increased monitoring effort along the Brazilian coast; and/or (c) increased anthropogenic threats. Potential threats to this species include collisions with ships (Lodi et al., 2015; Stockin et al., 2008; Van Waerebeek et al., 2007), bycatch (Lodi et al., 2015), and noise and chemical pollution (Barreto et al., 2011).
Effective monitoring of strandings data, such as that used in this study, can inform management and conservation actions, and further studies could also improve understandings of Bryde's whale macroecology in the region. In addition, a higher number of stranded animal biopsies would further clarify the taxonomic status of the Bryde's whale in Brazil and contribute to the determination of whale stocks.

\section{ACKNOWLEDGEMENTS}

The author would like to thank Dr. Liliane Lodi of the Rio Islands Project and the Whales and Dolphins Project of Rio de Janeiro for encouraging this study, and for the critical suggestions and revision of the manuscript. Thanks are also due to PhD student Sérgio Moreira de Carvalho (PPGZOONational Museum/UFRJ) for his encouragement, significant collaboration during the map construction and for his suggestions to the manuscript, as well as to doctoral student Israel de Sá Maciel and Dr. Rodrigo Hipólito Tardin, from the Bioacoustics and Ecology Cetacean Laboratory/UFRRJ, for their collaboration on the manuscript and support in carrying out the statistical analyses.

\section{REFERENCES}

Andriolo, A., da Rocha, J.M., Zerbini, A.N., Simoes-Lopes, P.C., Moreno, I.B., Lucena, A., Danilewicz, D. and Bassoi, M. 2010. Distribution and relative abundance of large whales in a former whaling ground off eastern South America. Zoologia 27: 741-50.

Barreto, A.S., Rocha-Campos, C.C., Rosas, F.W., da Silva Jr, J.M., Rosa, L.D., Flores, P.A.C. and da Silva, V.M.F. 2011. Plano De Ação Nacional Para A Conservação Dos Mamíferos Aquáticos - Pequenos Cetáceos. ICMBio Report. 134pp. [Available at: http://www.icmbio. gov.br/portal/images/stories/docs-plano-de-acao/pan-peqs-cetaceos/panpequenoscetaceos-web.pdf]

Best, P.B. 2001. Distribution and population separation of Bryde's whale Balaenoptera edeni off southern Africa. Mar. Ecol. Progr. Ser. 220: 27789. 
Bittencourt, M.L. 1983. Primeiro registro de Bryde's whale Balaenoptera edeni (Cetacea, Balaenopteridae) para o litoral do Estado do Paraná Brasil. Arquivos Biológicos Tecnlogicos 26(4): 485.

Dalcin, C.R. 2009. Unesc exibe esqueleto de baleia. ZH Notícias. [Available at: http://anoticia.clicrbs.com.br/sc/geral/noticia/2009/06/unesc-exibeesqueleto-de-baleia-2549973.html; In Portuguese; Accessed 22 October 2015].

Davis, R.W., Fargion, G.S., May, N., Leming, T.D., Baumgartner, M., Evans, W.E., Hansen, L.J. and Mullin, K. 1998. Physical habitat of cetaceans along the continental slope in the north-central and western Gulf of Mexico. Mar. Mam. Sci. 14(3): 490-507.

de Moura, J.F. and Siciliano, S. 2012. Stranding pattern of Bryde's whales along the south-eastern coast of Brazil. Mar. Biodivers. Rec. 5: E73. [Available at: https://doi.org/10.1017/S1755267212000528].

Domingues, F. 2013. Baleia é encontrada morta na Juréia. Jornal Regional. [Available at: http://regionaljornal.blogspot.com/2013/05/meio-ambientebaleia-de-13-metros.html; In Portuguese; Accessed 22 October 2015].

Figueiredo, L.D., Tardin, R.H., Lodi, L., Maciel, I.S., Alves, M.A.S. and Simão, S.M. 2014. Site fidelity of Bryde's whales (Balaenoptera edeni) in Cabo Frio region, southeastern Brazil, through photoidentification technique. Braz. J. Aquat. Sci. Technol. 18(2): 59-64.

Gallardo, V.A., Arcos, D., Salamanca, M. and Pastene, L. 1983. On the occurrence of Bryde's whales (Balaenoptera edeni Anderson, 1878) in an upwelling area off central Chile. Rep. Int. Whal. Commn 33: 481-88.

Geise, L. and Borobia, M. 1988. Sobre a ocorrência de cetáceos no litoral do Estado do Rio de Janeiro entre 1968 e 1984. Revista Brasileira de Zoologia.4(4): 341-346.

G1 O Globo/Vale do Paraíba e região. 2015. Baleia é encontrada morta na praia de Caraguatatuba. [Available at: http://g1.globo.com/sp/vale-doparaiba-regiao/noticia/2015/10/baleia-e-encontrada-morta-em-praiade-caraguatatuba-sp.html; In Portuguese; Accessed 22 October 2015].

Gonçalves, L.R. and Andriolo, A. 2006. Ocorrência, distribuição e comportamento de baleias-debryde (Balaenoptera edeni Anderson, 1879) (Cetacea: Mysticeti) em zona costeira e oceânica do sudeste do Brasil. MSc Dissertation, Universidade Federal de Juiz de Fora, Brazil. 21pp. [In Portuguese].

Groch, K.R., Palazzo, J., J.T., Flores, P.A.C., Adler, F.R. and Fabian, M.E. 2005. Recent rapid increases in the right whale (Eubalaena australis) population off southern Brazil. LAJAM 4(1): 41-47.

Jefferson, T.A., Webber, M. and Pitman, R.L. 2008. Marine Mammals of the World: a Comprehensive Guide to their Identification. Academic Press, London. 573pp.

Kato, H. and Perrin, W. 2009. Bryde's whales Balaenoptera edeni/ brydei. pp.158-63. In: W. Perrin, B. Würsig and J. Thewissen (eds). Encyclopedia of Marine Mammals (2nd Ed.). Academic Press, Amsterdam, Netherlands.

Kerosky, S.M., Širović, A., Roche, L.K., Baumann-Pickering, S., Wiggins, S.M. and Hildebrand, J.A. 2012. Bryde's whale seasonal range expansion and increasing presence in the Southern California Bight from 2000 to 2010. Deep Sea Res. I: Oceanogr. Res. Pap. 65: 125-32.

Lima, A.F.B., Gonçalves, L.R. and de Queiroz, E.L. 2006. Registro histórico de encalhe de uma Baleia-de-Bryde Balaenoptera edeni Anderson, 1879 (Mysticeti: Balaenopteridae), no Rio Piraguaçu, baía de todos os santos, Bahia, Brasil. Bioikos 20(2): 75-79. [In Portuguese].

Lodi, L. and Borobia, M. 2013. Baleias, Botos e Golfinhos do Brasil: Guia de Identificação. 1st Edn. Technical Books Editora, Rio de Janeiro.

Lodi, L and Tardin, R. 2014. Baleias-de-bryde: nômades do oceano. InforMar 21:8-10.

Lodi, L., Tardin, R.H., Hetzel, B., Maciel, I.S., Figueiredo, L.D. and Simao, S.M. 2015. Bryde's whale (Cetartiodactyla: Balaenopteridae) occurrence and movements in coastal areas of southeastern Brazil. Zoologia 32: 17175 .

Magalhães, F.A.,Tosi, C,H.,Garri, C.H., Chellappa, S. and Silva, F.L. 2008 Cetacean diversity on the Parnaiba Delta, Maranhão state, northeastern Brazil. Brazilian J. Biol. 68(3): 545-551.

Maldini, D., Mazzucca, L. and Atkinson, S. 2005. Odontocete stranding patterns in the main Hawaiian islands (1937-2002): how do they compare with live animal surveys? Pacific Science 59(1): 55-67.

Marchi, C. 2014. Baleia é encontrada morta em Atlântida Sul, no Litoral Norte. Correio do Povo. [Available at: https://www.correiodopovo.com. $\mathrm{br} /$ not $\% C 3 \% A D$ cias/geral/baleia- $\% C 3 \% A 9$-encontrada-morta-ematl\%C3\%A2ntida-sul-no-litoral-norte-1.158361, In Portuguese; Accessed 22 October 2015].
Meager, J.J. and Limpus, C. 2014. Mortality of inshore marine mammals in eastern Australia is predicted by freshwater discharge and air temperature. PloS One 9(4): e94849.

Meager, J.J. and Sumpton, W.D. 2016. Bycatch and strandings programs as ecological indicators for data-limited cetaceans. Ecol. Indic. 60: 98795.

Moreira, L.M.D.P., Rocha, M.E.C; Groch, K.R., Freitas, R., Bom, K.C.M., Flores, P.A.C., Pretto, D., Corrêa, A.A., Farias, D.S., Guimarães, G.M Martins, L., Amorim, W. 2010. Protocolo de Encalhes na APA da Baleia Franca: o caso da Baleia de Bryde no Costão de Itapiruba, SC. In Reunião de Trabalhos de Especialistas em Mamíferos Aquáticos da América do Sul. Congressos Solamac 8: 24-28.

Moura, J.F. and Siciliano, S. 2012. Stranding pattern of Bryde's whales along the south-eastern coast of Brazil. Mar. Biodivers. Rec. 5: E73. [Available at: https://doi.org/10.1017/S1755267212000528].

Palacios, D.M. 2003. Oceanographic conditions around the Galapagos Archipelago and their influence on cetacean community structure. $\mathrm{PhD}$, Oregon State University, Corvallis, Oregon. 178pp.

Papa-Berbigão. 2014. Baleia encalhada chamou a atenção nesta segunda no norte da ilha. [Available at: https://papaberbigao.wordpress.com/2014/ 06/24/baleia-encalhada-chamou-a-atencao-nesta-segunda-no-norte-dailha; In Portuguese; Accessed 22 October 2015].

Pardo, M.A. and Palacios, D.M. 2006. Cetacean occurrence in the Santa Marta region, Colombian Caribbean, 2004-2005. LAJAM 5(2): 129-34.

Pastene, L.A., Acevedo, J., Siciliano,S., Sholl, T.G., Moura, J.F., Ott, P.H., Aguayo-Lobo, A. 2015. Population genetic structure of the South American Bryde's whale. Revista de Biología Marina y Oceanografía. 50(3): 453-464.

Peltier, H., Jepson, P.D., Dabin, W., Deaville, R., Daniel, P., Van Canneyt, O. and Ridoux, V. 2014. The contribution of stranding data to monitoring and conservation strategies for cetaceans: Developing spatially explicit mortality indicators for common dolphins (Delphinus delphis) in the eastern North-Atlantic. Ecol. Indic. 39: 203-14

Pereira, J.M. 2014. Baleia encontrada encalhada em São Francisco do Sul será alvo de estudos. Notícias do Dia. [Available at: https://ndonline. com.br/joinville/noticias/baleia-encontrada-encalhada-em-saofrancisco-do-sul-sera-alvo-de-estudos; In Portuguese; Accessed 22 October 2015]

Santos, M., Siciliano, S., Castro Vincente, A.F., Alvarenga, F., Zampirolli, E., Pacheco de Souza, S. and Maranho, A. 2010. Cetacean records along Sao Paulo state coast, southeastern Brazil. Braz. J. Oceanogr. 58(2): 123 42.

Siciliano, S., de Oliveira Santos, M.C., Vicente, A.F.C., Alvarenga, F.S. Zampirolli, E., Brito, J.L., Azevedo, A.F. and Pizzorno, J.L.A. 2004 Strandings and feeding records of Bryde's whales (Balaenoptera edeni) in south-eastern Brazil. J. Mar. Biol. Assoc. UK 84(4): 857-59.

Soto, J.M.R., Silva-Ribeiro, C.C. and Miranda, C.M. 2001. In: SIMMAM. Sistema de Apoio ao Monitoramento de Mamíferos Marinhos/ Universidade do Vale do Itajaí. [Available at: http://simmam.acad. univali.br/site; In Portuguese; Accessed 25 November 2015].

Stockin, K.A., Wiseman, N., Hartman, A., Moffat, N. and Roe, W.D. 2008. Use of radiography to determine age class and assist with the post mortem diagnostics of a Bryde's whale (Balaenoptera brydei). New Zealand J. Mar. Fresh. Res. 42(3): 307-13.

Tershy, B.R., Breese, D. and Strong, C.S. 1990. Abundance, seasonal distribution and population composition of balaenopterid whales in the Canal de Ballenas, Gulf of California, México. Rep. Int. Whal. Commn (special issue) 12: 369-75.

Torales, E. 2014. Carcaça de baleia é encontrada na praia do Cassino. Agora O Jornal do Sul. [Available at: http://www.oceanofm.com. br index.php? $n$ sistema $=8024 \&$ id noticia $=M T Q 3 O A==$ \&id area $=M A$; In Portuguese. Accessed 22 October 2015].

Van Waerebeek, K., Baker, A.N., Félix, F., Gedamke, J., Iñiguez, M., Sanino, P.G., Secchi, E., Sutaria, D., van Helden, A. and Wang, Y. 2007. Vessel collisions with small cetaceans worldwide and with large whales in the Southern Hemisphere; an initial assessment. LAJAM 6(1): 43-69.

Zerbini, A.N., Clapham, P.J. and Wade, P.R. 2010. Assessing plausible rates of population growth in humpback whales from life-history data. Mar. Biol. 157(6): 1,225-36.

Zerbini, A.N., Secchi, E.R., Siciliano, S. and Simöes-Lopes, P.C. 1997. A review of the occurrence and distribution of whales of the genus Balaenoptera along the Brazilian coast. Rep. Int. Whal. Commn 47: 40717. 